\title{
Risk Factors for Rebleeding of Aneurysmal Subarachnoid Hemorrhage Based on the Analysis of On-Admission Information
}

\author{
Kabul Zamanindaki Bilginin Analizi Temelinde Anevrizmal \\ Subaraknoid Kanamada Tekrar Kanama İcin Risk Faktörleri
}

Wu CONG, Zhao ZHONGXIN, Li TIANGUI, Yu ZHANG, He MIN, You CHAO

West China Hospital, Sichuan University, Department of Neurosurgery, Chengdu, Sichuan Province, China

Correspondence address: Min HE / E-mail: minghewc@yahoo.com.cn

\begin{abstract}
AIM: To provide a quick evaluation of rebleeding risk based on the on-admission patient information and to guide the management of patients for better outcome.

MATERIAL and METHODS: A retrospective review of 630 consecutive cases of subarachnoid hemorrhage (SAH) at a major medical center was conducted, of which 458 were included for analysis. Sixty three cases of in-hospital pre-intervention rebleeding were identified. Chi-square or Mann-Whitney tests were used to screen for possible risk factors and values of the associated risk factors were assessed by logistic multivariate regression.

RESULTS: The identified risk factors were: short time interval between the first attack and hospitalization, gender (males were more susceptible), poor Hunt-Hess grade (III V), high systolic pressure $(>140 \mathrm{mmHg})$, intracerebral or intraventricular hematoma, high level of serum glucose $(>6.32 \mathrm{mmol} / \mathrm{L})$ and high white blood cell count $\left(>12 \times 10^{\wedge} \mathrm{g} / \mathrm{L}\right)$. Use of antifibrinolysis medication did not differ between groups. Subgroup analysis showed that posterior circulation aneurysms had a significantly higher rebleeding rate. Logistic regression analysis showed that intracerebral or intraventricular hematoma $(p=0.010, O R=1.478)$ and blood glucose level above $6.32 \mathrm{mmol} / \mathrm{L}(\mathrm{p}=0.011, \mathrm{OR}=2.126)$ were independent risk factors.
\end{abstract}

CONCLUSION: We found a particularly high risk of rebleeding in patients with intracerebral or intraventricular hematoma or relatively high serum glucose level on admission. Posterior circulation aneurysms rebleed seemed more prominently manifested. An earlier and more aggressive intervention may be applied to patients at high risk.

KEYWORDS: Subarachnoid hemorrhage, Intracranial aneurysms, Rebleeding, Risk factor

öz

AMAÇ: Kabul zamanındaki hasta bilgisi temelinde tekrar kanama riskinin hızlı bir değerlendirmesini sağlamak ve daha iyi bir sonuç için hasta takibine rehberlik yapmak.

YÖNTEM ve GEREÇLER: Büyük bir tıbbi merkezde arka arkaya 630 subaraknoid kanama (SAK) vakasının retrospektif bir gözden geçirilmesi yapıldı ve bunların 458'i analize alındı. Hastanede girişim öncesi tekrar kanama 63 vakada tanımlandı. Olası risk faktörleri için taramak amacıyla ki kare veya Mann-Whitney testleri kullanıldı ve ilgili risk faktörlerinin değerleri lojistik multivaryant regresyonla değerlendirildi.

BULGULAR: Tanımlanmış risk faktörleri şunlardır: birinci atak ile hastaneye yatma arasında kısa süre, cinsiyet (erkekler daha yatkındı), kötü Hunt-Hess sınıfı (III V), yüksek sistolik basınç (>140 mmHg), intraserebral veya intraventriküler hematom, yüksek serum glukoz düzeyi (> 6,32 $\mathrm{mmol} / \mathrm{L}$ ) ve yüksek lökosit sayısı (> 12×10^9/L). Antifibrinoliz ilaçlarının kullanımı gruplar arasında farklılık göstermedi. Alt grup analizi posterior dolaşım anevrizmalarının daha yüksek bir tekrar kanama oranı olduğunu gösterdi. Lojistik regresyon analizi intraserebral veya intraventriküler hematomun ( $p=0,010, O R=1,478)$ ve $6,32 \mathrm{mmol} / \mathrm{L}$ üzerinde glukoz düzeyinin $(\mathrm{p}=0,011, \mathrm{OR}=2,126)$ bağımsız risk faktörleri olduklarını gösterdi.

SONUÇ: Intraserebral veya intraventriküler hematomu olan veya kabul zamanında serum glukoz düzeyi nispeten yüksek hastalarda özellikle yüksek bir tekrar kanama riski bulduk. Posterior dolaşım anevrizmalarının tekrar kanaması daha belirgin gibiydi. Yüksek riskli hastalarda daha erken ve daha agresif bir girişim kullanılabilir.

ANAHTAR SÖZCÜKLER: Subaraknoid kanama, İntrakraniyal anevrizmalar, Tekrar kanama, Risk faktörü 


\section{INTRODUCTION}

Rebleeding is a severe and devastating complication of aneurysmal subarachnoid hemorrhage, with a reported mortality rate of $80 \%$ (19). It is now recognized that early surgical intervention can effectively prevent rebleeding. However, in developing nations, the patient transport system and hospital conditions make early intervention difficult. Thus, immediate evaluation of the risk for rebleeding upon admission could provide a selective earlier and more aggressive intervention in high-risk cases. There have been several previous reports about the predictive factors of aneurysmal SAH (aSAH) rebleeding $(19,20)$, but the studies could not provide statistical comparisons due to the small sample size. Additionally, studies have focused on risks of ultra-early rebleeding and do not include patients who had a delayed hospital admission $(8,9)$.

Our institution is a major medical center in western China to which many SAH patients are transported from rural areas. A considerable number of patients had their aneurysms sealed after 2 weeks of the ictus. Consequently, we are able to observe a wide range of $\mathrm{SAH}$ patients. In this study, we retrospectively reviewed 630 consecutive SAH patients who were admitted to our hospital between January 2005 and December 2008. A subset of 458 cases, including 63 rebleeding cases, was included for analysis. After identification of several risk factors for rebleeding based on the admission information, logistic regression analysis was performed to determine the predictive value of those factors.

\section{MATERIAL and METHODS}

From the Medical Document Store Department of our institution, we obtained the charts of 630 patients who were admitted to our service between January 2005 and December 2008 with a diagnosis of spontaneous SAH by initial Computed Tomography (CT) scan performed directly upon admission. Among those patients, 65 had negative Digital Subtraction Angiography (DSA) results. An additional 29 patients were unable to be tested by this method due to rapid deterioration but a typical CT scan indicated an aneurismal origin of the $\mathrm{SAH}$. The remaining 536 individuals harbored aneurysms confirmed by DSA. The latter two kinds of patients (565 cases) mentioned above were regarded as aSAH patients, and 458 of them were admitted to our hospital within 30 days of the first insult (Figure 1).

The charts of the 458 aSAH patients with adequate baseline information were carefully reviewed. Whether patients had rebleeding was determined by repeated $\mathrm{CT}$ scans presenting an increase of subarachnoid, intracerebral, or intraventricular hematoma, or by changes noted in documented clinical signs, such as sudden deterioration of consciousness and sudden apnea. The 63 cases defined as having rebleeding after admission were assigned as the rebleeding group and the remaining 395 cases were assigned as the non- rebleeding group (Table I).

The risk factors were then analyzed with a focus on onadmission information such as age, gender, time interval between the first attack and admission, Hunt-Hess grade (11), systolic blood pressure, initial CT presentation, history of using antifibrinolytic medication, and hematological parameters including WBC counting, platelet counting, and serum fibrinogen and glucose levels. Parameters were identified by the Receiver Operating Characteristic (ROC) analysis or by review of literature to classify those positive results for logistic regression.

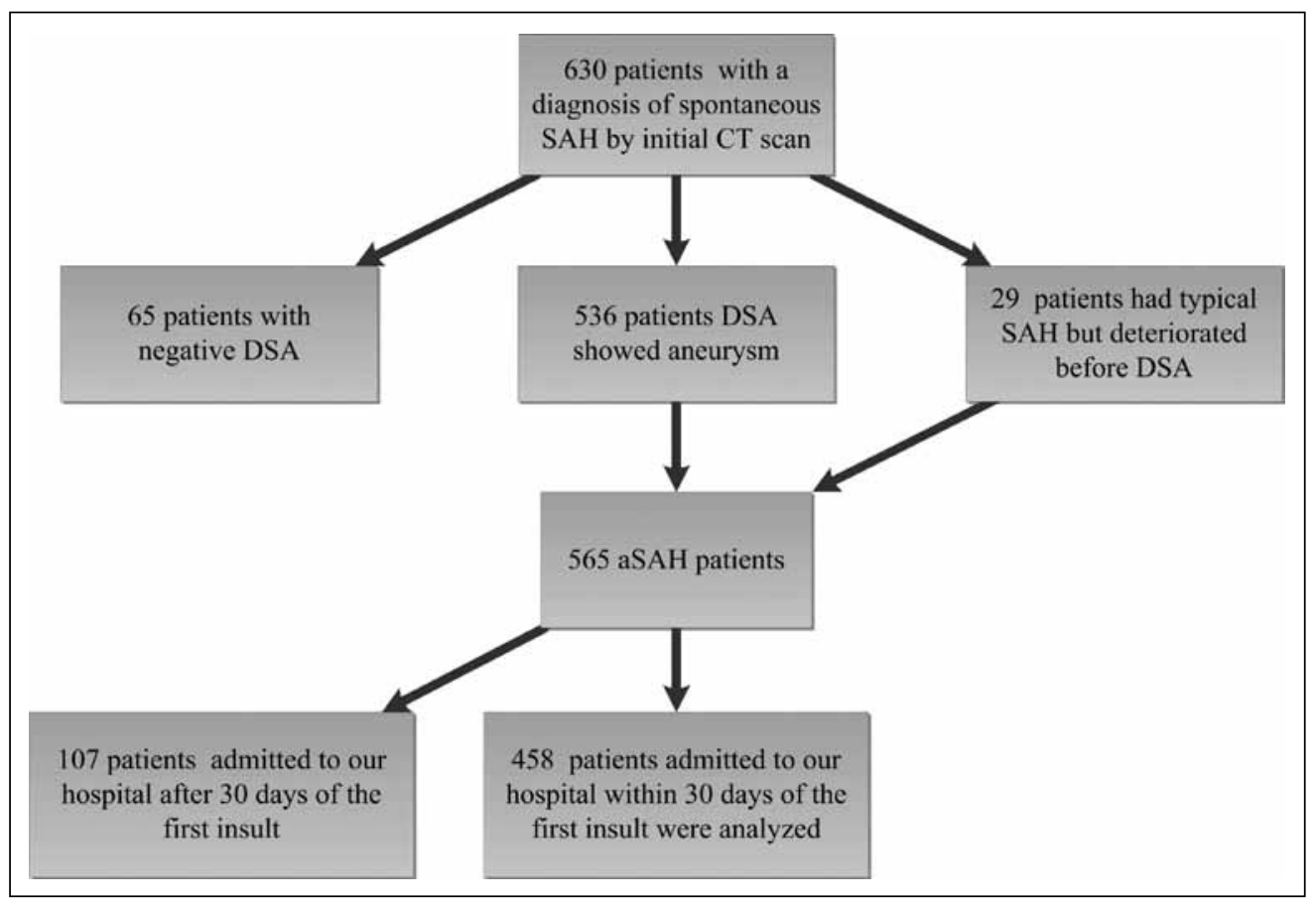

Figure 1: Patient selection procedure. 
Table I: Patient On-Admission Characteristics and Relationship to Rebleeding

\begin{tabular}{|c|c|c|c|c|}
\hline & $\begin{array}{l}\text { Non-rebleeding } \\
\quad(\mathrm{N}=395)\end{array}$ & $\begin{array}{l}\text { Rebleeding } \\
\qquad(\mathrm{N}=63)\end{array}$ & $\begin{array}{c}\text { Total } \\
(\mathrm{N}=458)\end{array}$ & P value \\
\hline \multicolumn{5}{|l|}{ Gender } \\
\hline Male & 147 & 32 & 179 & \multirow{2}{*}{$0.040^{*}+$} \\
\hline Female & 248 & 31 & 279 & \\
\hline \multicolumn{5}{|l|}{ Age } \\
\hline$M d \pm Q$, year & $53 \pm 17$ & $55 \pm 20$ & & $0.405^{\ddagger}$ \\
\hline \multicolumn{5}{|l|}{ Hunt-Hess grade } \\
\hline I & 155 & 13 & 168 & \multirow{5}{*}{$0.045^{* \S}$} \\
\hline II & 129 & 25 & 154 & \\
\hline III & 65 & 13 & 78 & \\
\hline IV & 36 & 12 & 48 & \\
\hline V & 10 & 0 & 10 & \\
\hline \multicolumn{4}{|l|}{ CT presentation } & \multirow{3}{*}{$0.002^{*+}$} \\
\hline Without IIHI"\# & 328 & 42 & 370 & \\
\hline With IIH ${ }^{\prime \#}$ & 67 & 21 & 88 & \\
\hline \multicolumn{5}{|l|}{ Time interval between FAA ${ }^{* *}$} \\
\hline$M d \pm Q$, day & $4 \pm 9$ & $2 \pm 7$ & & \multirow{3}{*}{$\begin{array}{l}0.019^{*} \ddagger \\
0.018^{* \dagger}\end{array}$} \\
\hline$\leq 2$ & 128 & 30 & 158 & \\
\hline$>2$ & 267 & 33 & 300 & \\
\hline \multicolumn{5}{|l|}{ Systolic BP } \\
\hline$M d \pm Q, \mathrm{mmHg}$ & $133 \pm 33$ & $140 \pm 28$ & & \multirow{3}{*}{$\begin{array}{l}0.013^{* \ddagger} \\
0.026^{* \dagger}\end{array}$} \\
\hline$\leq 140$ & 253 & 31 & 284 & \\
\hline$>140$ & 142 & 32 & 174 & \\
\hline \multicolumn{5}{|l|}{ PLT } \\
\hline$M d \pm Q, \times 10^{9} / \mathrm{L}$ & $158 \pm 85$ & $145 \pm 94$ & & $0.393^{\ddagger}$ \\
\hline \multicolumn{5}{|l|}{ FIB } \\
\hline$M d \pm Q, \mathrm{~g} / \mathrm{L}$ & $3.56 \pm 1.54$ & $3.70 \pm 1.55$ & & $0.332^{\ddagger}$ \\
\hline \multicolumn{5}{|l|}{ Serum glucose } \\
\hline$M d \pm Q, \mathrm{mmol} / \mathrm{L}$ & $6.31 \pm 2.83$ & $7.10 \pm 2.92$ & & \multirow{3}{*}{$\begin{array}{l}0.015^{*} \\
0.003^{* \dagger}\end{array}$} \\
\hline$\leq 6.32$ & 198 & 19 & 217 & \\
\hline$>6.32$ & 197 & 44 & 241 & \\
\hline \multicolumn{5}{|l|}{ WBC counting } \\
\hline$M d \pm Q, \times 10^{9} / \mathrm{L}$ & $9.86 \pm 6.22$ & $11.70 \pm 4.30$ & & \multirow{3}{*}{$\begin{array}{c}<0.001^{*} \neq \\
0.045^{* \dagger}\end{array}$} \\
\hline$\leq 12 \times 10^{9} / \mathrm{L}$ & 267 & 34 & 301 & \\
\hline$>12 \times 10^{9} / \mathrm{L}$ & 128 & 29 & 157 & \\
\hline \multicolumn{5}{|l|}{ History of medication } \\
\hline With antifibrinolyisis & 135 & 23 & 158 & \multirow{2}{*}{0.776} \\
\hline Without antifibrinolyisis & 260 & 40 & 300 & \\
\hline
\end{tabular}

${ }^{*} P<0.05 ;{ }^{+}$Chi-square test; ${ }^{*}$ Mann-Whitney test; ${ }^{\S}$ Chi-square test with Hunt-Hess grade classified as I II versus III V; ${ }^{\mid+\# ~ I I H, ~ I n t r a c e r e b r a l ~ o r ~}$ Intraventricular Hematoma; * FAA, First Attack and Admission. 
All data were analyzed using PASW Statistics 18.0. The MannWhitney and Chi-square tests were used to screen factors between the rebleeding and non-rebleeding groups. For logistic regression, $\mathrm{ROC}$ analysis was employed to find the dividing level of time interval between the first attack and admission and the blood glucose level on admission. The Chinese diagnostic standard of $140 \mathrm{mmHg}$ (4) was used to classify the patients for logistic analysis of hypertension. We used white blood cell (WBC) count of $12 \times 10^{\wedge} 9 / \mathrm{L}$ as the cutoff as it is one of the defined levels of systemic inflammatory response syndrome (SIRS) (1). Forward Stepwise (Wald) logistic regression analysis was used to identify the independent factors predicting rebleeding. To analyze the influence of aneurysm location, Chi-square test was applied after excluding the cases without DSA exams. For all tests, P-values $<0.05$ were considered to indicate statistical significance.

\section{RESULTS}

\section{Time interval between first attack and rebleed}

The distribution of the time interval between first attack and rebleed of the 63 cases is shown as Figure 2. We can observe two prominent peaks at the $3 \mathrm{rd}$ to 4 th and the 11 th to 12 th day after the first ictus.

\section{Univariate analysis of risk factors for rebleeding}

Risk factors for rebleeding were male gender, Hunt-Hess grade III to $\mathrm{V}$, initial CT presentation of intracerebral or intraventricular hematoma, short time interval between first attack and admission, high level of systolic blood pressure, serum glucose and WBC count on admission (Table I). The distribution profile of time interval between first attack and admission of the two groups is shown in Figure 3. By ROC analysis, the maximal sum of sensitivity and specificity were 1.5 days and $6.32 \mathrm{mmol} / \mathrm{L}$ for interval between first attack and admission and level of serum glucose, respectively (Figure 4A, $B)$. Therefore, for logistic analysis, we used the values of 2 days

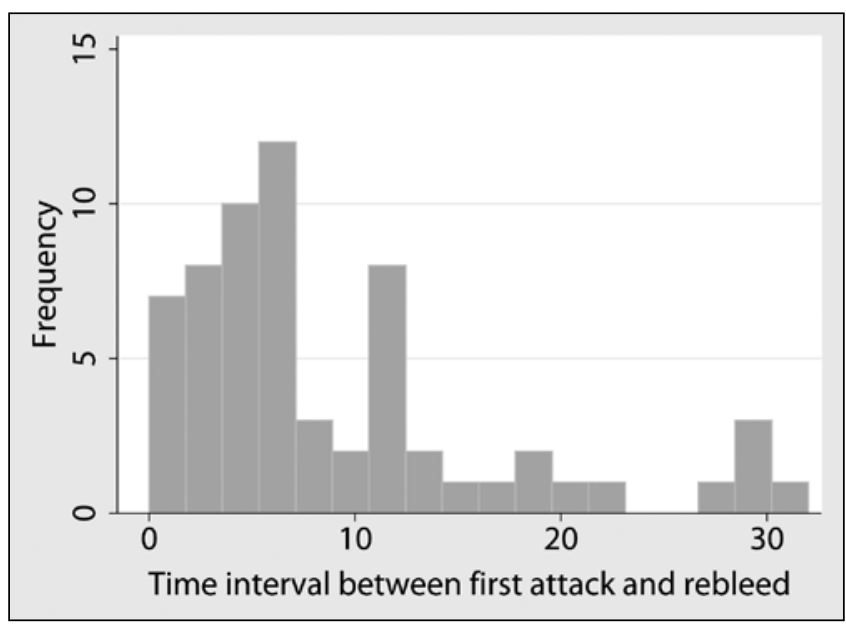

Figure 2: Distribution of time interval between first attack and rebleed of the 63 patients.

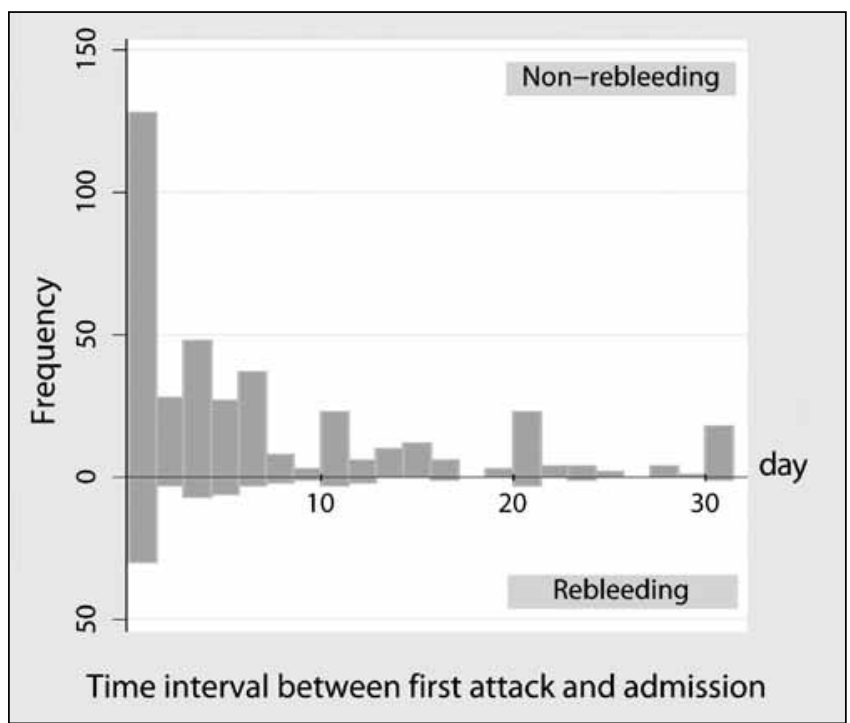

Figure 3: Comparison of distribution of time interval between first attack and admission of the two groups.

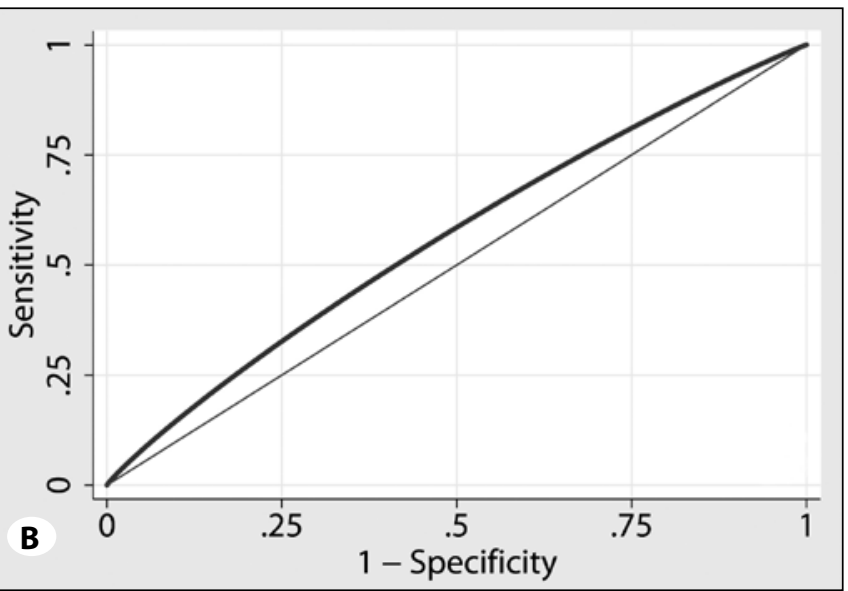

Figure 4: ROC analysis to determine dividing values for various parameters. A) To distinguish time interval between last attack and admission between the two groups, area under the curve $=0.5915$ with S.E. $=0.0022 ; 1.5$ day was the maximal sum of sensitivity and specificity time. B) To distinguish serum glucose level between the two groups, area under the curve $=0.5611$ with S.E. $=0.0432 ; 6.32$ $\mathrm{mmol} / \mathrm{L}$ was the maximal sum of sensitivity and specificity value. 
and $6.32 \mathrm{mmol} / \mathrm{L}$ as cutoffs for interval and glucose levels, respectively. Other parameters, such as age, platelet level, serum fibrinogen level, and history of using antifibrinolytic medication did not show statistically significant difference.

\section{Multivariate analysis of risk factors for rebleeding}

The positive risk factors were stratified and included in a multivariate logistic regression (Table II). The analysis revealed that only two variables were independently related to rebleeding-intracerebral or intraventricular hematoma on the initial CT scan $(p=0.010, O R=1.478)$ and serum glucose above $6.32 \mathrm{mmol} / \mathrm{L}(\mathrm{p}=0.011, \mathrm{OR}=2.126)$.

\section{Subgroup analysis of aneurysm location}

After exclusion of the 29 cases without DSA due to rapid deterioration, the remaining 429 cases with 54 rebleed cases were divided by aneurysm location into the following 5 aspects: 1) anterior cerebral artery (ACA) or anterior communicating artery (AComA), 2) posterior communicating artery (PComA) and internal carotid artery (ICA), 3) middle cerebral artery (MCA), 4) posterior circulation region, and 5) multiple aneurysms. The Chi-square test results of each aspect of location are shown in Table III. Only posterior circulation aneurysms showed significantly higher rebleeding risk $(34.0 \%)$ than the non-posterior circulation aneurysms (11.4\%).

\section{DISCUSSION}

Our study only included parameters that were available within a short time upon admission. Our findings could provide neurologists, neurosurgeons, neuro-interventionalists, and emergency physici(ans, especially those in underdeveloped regions, with a simple and fast method to evaluate the rebleeding risk for aSAH patients.

\section{Time interval between first attack and rebleed}

We found that $37 \%$ of the rebleeding happened in the $3^{\text {rd }}$ to $7^{\text {th }}$ day after first attack, and a second peak was observed during the $11^{\text {th }}$ to $12^{\text {th }}$ day (Figure 2). This is in contrast to earlier studies that found that the peak of rebleeding was $6^{\text {th }}$ to $11^{\text {th }}$ day or in the first day of SAH $(16,17)$. But Brilstra $\mathrm{EH}$ et al. recently calculated the rebleeding incidence every two days after the initial SAH and reported that the highest incidences occurred during the first two days, gradually decreased, and then increased in the $12^{\text {th }}$ day (2). As such, the rebleeding ratio we observed and the rebleeding incidence

Table II: Results of Logistic Stepwise Regression Analysis

\begin{tabular}{|c|c|c|c|c|c|c|c|}
\hline & \multirow{2}{*}{ B } & \multirow{2}{*}{ S.E. } & \multirow{2}{*}{ Wald $X^{2}$} & \multirow{2}{*}{ P value } & \multirow{2}{*}{ OR } & \multicolumn{2}{|c|}{$95 \% \mathrm{Cl}$} \\
\hline & & & & & & Lower & Upper \\
\hline Gender (male) & - & - & - & 0.079 & - & - & - \\
\hline Hunt-Hess grade (III-V) & - & - & - & 0.885 & - & - & - \\
\hline $\mathrm{CT}_{\text {presentation }}^{\dagger}$ & 0.391 & 0.152 & 6.623 & $0.010^{*}$ & 1.478 & 1.098 & 1.991 \\
\hline Time interval between FAA ${ }^{\ddagger}$ & - & - & - & 0.126 & - & - & - \\
\hline Systolic BP (>140 mmHg) & - & - & - & 0.089 & - & - & - \\
\hline Serum glucose (>6.32 mmol/L) & 0.754 & 0.296 & 6.474 & $0.011^{*}$ & 2,126 & 1.189 & 3.800 \\
\hline WBC counting $\left(>12 \times 10^{9} / L\right)$ & - & - & - & 0.454 & - & - & - \\
\hline
\end{tabular}

${ }^{*} P<0.05 ;{ }^{+}$with intracerebral or intraventricular hematoma; ${ }^{*}$ first attack and admission less than 2 days; S.E, Standard Error.

Table III: Results Of Subgroup Analysis of Aneurysm Location

\begin{tabular}{|c|c|c|c|c|}
\hline & & $\begin{array}{l}\text { Non-rebleeding } \\
\quad(\mathrm{N}=375)\end{array}$ & $\begin{array}{l}\text { Rebleeding } \\
\qquad(\mathrm{N}=54)\end{array}$ & P value \\
\hline ACA/AComA & $\begin{array}{l}\text { Yes } \\
\text { Non }\end{array}$ & $\begin{array}{l}115 \\
260\end{array}$ & $\begin{array}{l}14 \\
40\end{array}$ & 0.478 \\
\hline MCA & $\begin{array}{l}\text { Yes } \\
\text { Non }\end{array}$ & $\begin{array}{r}31 \\
344\end{array}$ & $\begin{array}{r}5 \\
49\end{array}$ & 0.806 \\
\hline ICA/PComA & $\begin{array}{l}\text { Yes } \\
\text { Non }\end{array}$ & $\begin{array}{l}153 \\
222\end{array}$ & $\begin{array}{l}15 \\
39\end{array}$ & 0.067 \\
\hline Post circulation & $\begin{array}{l}\text { Yes } \\
\text { Non }\end{array}$ & $\begin{array}{r}16 \\
359\end{array}$ & $\begin{array}{r}8 \\
46\end{array}$ & $0.002^{*}$ \\
\hline Multiple aneurysm & $\begin{array}{l}\text { Yes } \\
\text { Non }\end{array}$ & $\begin{array}{r}60 \\
315\end{array}$ & $\begin{array}{l}12 \\
42\end{array}$ & 0.252 \\
\hline
\end{tabular}


mentioned above both indicated a second increase in the $12^{\text {th }}$ day after the initial ictus. This may resulted from a gradual dissolution of the blood clot that stopped the first SAH. Based on this finding, we suggest that even a delayed surgery for aSAH should be scheduled before the $11^{\text {th }}$ day following the initial hemorrhage.

\section{Time interval between first attack and admission}

Patients who were admitted within 2 days after their first SAH had a significantly higher rebleeding rate than those who did not. Combined with our finding that the first rebleeding peak was in the $3^{\text {rd }}$ to $7^{\text {th }}$ day, this result could be explained as an overlap between the first rebleeding peak of patients and the early days of admission. As many patients of our hospital were transferred from rural areas, we may have missed those who died of rebleeding during transportation or at their local hospital. Y. Fujii had reported that the majority of rebleeding episodes occurred within 6 hours of SAH onset (8). Thus the fast diagnosis and transfer of $\mathrm{SAH}$ patients is essential for improving outcome.

\section{Gender and age}

Our analysis showed that rebleeding risk for males was significantly higher than for females. Although the age of 50 prominently separates the age distribution of the whole group, there was no significant difference of rebleeding risk between the two groups. These findings were quite different from other reports that claim that female and aged patients (> 60 years) had a higher risk $(17,13)$. There may be a racial or lifestyle difference associated with rebleeding risk since Chinese males have a greater smoking rate than females; smoking can potentially damage blood vessels and increase risk.

\section{Hunt-Hess grade, blood pressure, and CT presentation on admission}

The findings of poor Hunt-Hess grade (III V), initial CT presented intracerebral or intraventricular hematoma, and high level of systolic blood pressure as risk factors for rebleeding did not differ from previous studies $(8,10,18,19$, $21)$. It should be taken into consideration that patients with intracerebral or intraventricular hematoma often presented with a poor grade and high blood pressure on admission. This may be associated with pre-hospital or ultra-early rebleeding. Our study also found intracerebral or intraventricular hematoma to be independent risk factors of rebleeding with higher predictive value, thus warranting that patients who present with these conditions be treated and transferred more aggressively.

\section{High level of serum glucose and white blood cell count}

We found that a high level of serum glucose ( $>6.32 \mathrm{mmol} / \mathrm{L})$, an independent risk factor, and WBC count (> 12×10^9/L) were risk factors for rebleeding. Plenty of studies have revealed that hyperglycemia is associated with poor outcome and ischemic events after SAH (5. 7. 14. 22). The explanation provided was that hyperglycemia was associated with other complications such as congestive heart failure, respiratory failure, pneumonia, and brain stem compression from herniation (7). Our finding that hyperglycemia is related to rebleeding may be another reason for poor outcome due to the condition.

No relationship has been revealed between WBC count and rebleeding previous to our study, although high level of leukocyte count was reported to be associated with an increased risk of delayed cerebral ischemia after aSAH (15). It has also been shown that in mice, leukocytes and platelets adhere the microvasculature at the cerebral surface immediately after SAH.This may rapidly cause a whole-brain injury due to early inflammatory and prothrombogenic responses (12). Thus leukocytes may induce damage directly to the aneurysm wall and result in rebleeding.

Meanwhile, hyperglycemia present in patients with ischemic and hemorrhagic strokes is regarded as "stress hyperglycemia" and Capes SE et al. indicated that hyperglycemia after SAH was caused by a disturbance of hypothalamic regulation (3). Stress could also cause an increase of the WBC count. Since the increased levels of both the glucose and WBC are risk factors of rebleeding, we hypothesize that patients' stress conditions are related to the risk of rebleeding. The research of Dilraj A and his associates has supported the possibility that damage to the hypothalamus and subsequent elevations in catecholamine levels may be associated with focal ischemic deficit and poor clinical outcome after SAH. However, there is still lack of studies to reveal the relationship between catecholamine levels and rebleeding (6).

\section{Location of aneurysm}

There is controversy about which aneurysm location is most susceptible to rebleed. Some reported PcomA and AcomA had a higher risk (17), while others reported that posterior circulation aneurysms are more likely to rebleed (8). In subgroup analysis, we also found that posterior circulation aneurysms showed significantly higher rebleeding risk than those in the non-posterior circulation. This finding may be due to the fact that these aneurysms are near the brainstem and would have a predominant clinical manifestation once they rebleed. Patients with multiple aneurysms $(16.8 \%$ of total cases) were separately analyzed as one aspect because they had potentially high risk for rebleed due to an increased number of origins of hemorrhage. The rate of rebleeding for multiple aneurysms was $16.7 \%$ and was not significantly different from the $11.8 \%$ of the non-multiple group.

\section{History of antifibrinolytic medication}

It had been widely reported that antifibrinolytic therapy can reduce rebleeding but cannot improve overall outcome as it increases the rate of ischemic events. But in our study no significant decrease of rebleed was found for patients with history of antifibrinolytic medication. This may be because of differences in dosage and course of antifibrinolytic medication administered by other facilities; our institution does not regularly use antifibrinolytic medication. This analysis also 
rules out the effect of antifibrinolytic medication as the most possible influence factor in the pre-admission period.

\section{CONCLUSION}

We observed a particularly high risk of rebleeding among patients who had intracerebral or intraventricular hematoma on the initial CT scan or a relatively high serum glucose level on-admission. The identification of high level of serum glucose and WBC count as risk factors for rebleeding might indicate that patients' stress responses could be related to rebleed. Based on the on-admission information, an earlier and more aggressive intervention may be applied to patients at high risk.

\section{ACKNOWLEDGMENT}

This work is supported by the General Program No.30872673 and Youth Project No. 30801185 from National Natural Science Foundation of China.

\section{REFERENCES}

1. American College of Chest Physicians/Society of Critical Care Medicine Consensus Conference: Definitions for sepsis and organ failure and guidelines for the use of innovative therapies in sepsis. Critical Care Medicine 20: 864-874, 1992

2. Brilstra EH, Rinkel GJ, Algra A, van Gijn J: Rebleeding, secongdary ischemia, and timing of operation in patients with subarachnoid hemorrhage. Neurology 55:1656-1660, 2000

3. Capes SE, Hunt D, Malmberg K, Pathak P, Gerstein HC: Stress hyperglycemia and prognosis of stroke in nondiabetic and diabetic patients, a systematic overview. Stroke 32: 2426-2432, 2001

4. Chobanian AV, Bakris GL, Black HR, Cushman WC, Green LA, Izzo JL Jr, Jones DW, Materson BJ, Oparil S, Wright JT Jr, Roccella EJ: Seventh report of the Joint National Committee on Prevention, Detection, Evaluation, and Treatment of High Blood Pressure. Hypertension 42: 1206, 2003

5. Claassen J, Vu A, Kreiter KT, Kowalski RG, Du EY, Ostapkovich N, Fitzsimmons BF, Connolly ES, Mayer SA: Effect of acute physiologic derangements on outcome after subarachnoid hemorrhage. Critical Care Medicine 32:832-838, 2004

6. Dilraj A, Botha JH, Rambiritch V, Miller R, van Dellen JR: Levels of catecholamine in plasma and cerebrospinal fluid in aneurismal subarachnoid hemorrhage. Neurosurgery 31 : 42-51, 1992

7. Frontera JA, Fernandez A, Claassen J, Schmidt M, Schumacher HC, Wartenberg K, Temes R, Parra A, Ostapkovich ND, Mayer SA: Hyperglycemia after SAH: Predictors, associated complications, and impact on outcome. Stroke 37:199-203, 2006

8. Fujii Y, Takeuchi S, Sasaki O, Minakawa T, Koike T, Tanaka R: Ultra-early rebleeding in spontaneous subarachnoid hemorrhage. J Neurosurg 84:35-42, 1996
9. Fujii Y, Takeuchi S, Sasaki O, Minakawa T, Koike T, Tanaka R: Serial changes of hemostasis in aneurysmal subarachnoid hemorrhage with special reference to delayed ischemic neurological deficits. J Neurosurg 86: 594-602, 1997

10. Hijdra A, Vermeulen M, van Gijn J, van Crevel H: Rerupture of intracranial aneurysms: A clinicoanatomic study. J Neurosurg 67:29-33, 1987

11. Hunt WE, Hess RM: Surgical risk as related to time of intervention in the repair of intracranial aneurysms. J Neurosurg 28:14-20, 1968

12. Ishikawa M, Kusaka G, Yamaguchi N, Sekizuka E, Nakadate $H$, Minamitani H, Shinoda S, Watanabe E: Platelet and leukocyte adhesion in the microvasculature at the cerebral surface immediately after subarachnoid hemorrhage. Neurosurgery 64:546-553, 2009

13. Jamous MA, Nagahiro S, Kitazato KT, Tamura T, Kuwayama $\mathrm{K}$, Satoh K: Role of estrogen deficiency in the formation and progression of cerebral aneurysms. Part II: Experimental study of the effects of hormone replacement therapy in rats. J Neurosurg 103:1052-1057, 2005

14. Juvela S, Siironen J, Kuhmonen J: Hyperglycemia, excess weight, and history of hypertension as risk factors for poor outcome and cerebral infarction after aneurysmal subarachnoid hemorrhage. J Neurosurgery 102:998-1003, 2005

15. Kasius KM, Frijns CJ, Algra A, Rinkel GJ: Association of platelet and leukocyte counts with delayed cerebral ischemia in aneurysmal subarachnoid hemorrhage. Cerebrovascular Diseases 29:576-583, 2010

16. Kassell NF, Torner JC, Adams HP Jr: Aneurysmal rebleeding: A preliminary report from the Cooperative Aneurysm Study. Neurosurgery 13:479-481, 1983

17. Nibbelink DW, Torner JC, Henderson WG: Intracranial aneurysms and subarachnoid hemorrhage. A cooperative study. Antifibrinolytic therapy in recent onset subarachnoid hemorrhage. Stroke 6: 622-629, 1975

18. Ohkuma $H$, Tsurutani $H$, Suzuki S: Incidence and significance of early aneurysmal rebleeding before neurosurgical or neurological management. Stroke 32:1176-1180, 2001

19. Rosenorn J, Eskesen V, Schmidt K, Ronde F: The risk of rebleeding from ruptured intracranial aneurysms. J Neurosurg 67: 329-332, 1987

20. Steiger HJ, Fritschi J, Seiler RW: Current pattern of in-hospital aneurysmal rebleeds. Analysis of a series treated with individually timed surgery and intravenous nimodipine. Acta Neurochirurgica 127: 21-26, 1994

21. Torner JC, Kassell NF, Wallace RB, Adams HP Jr: Preoperative prognostic factors for rebleeding and survival in aneurysm patients receiving antifibrinolytic therapy: Report of the Cooperative Aneurysm Study. Neurosurgery 9:506-513, 1981

22. Wartenberg KE, Schmidt JM, Claassen J, Temes RE, Frontera JA, Ostapkovich N, Parra A, Connolly ES, Mayer SA: Impact of medical complications on outcome after subarachnoid hemorrhage. Critical Care Medicine 34:617-623, 2006 